\title{
Pelatihan Pengelolaan Sampah Melalui Bank Sampah di Desa Madyopuro Malang
}

\author{
Bagus Dwi Cahyono*1, Karno Setyo Budi² \\ 1Pendidikan Vokasional Teknik Elektro, Fakultas Keguruan Dan Ilmu Pendidikan, Universitas Sultan \\ Ageng Tirtayasa, Indonesia \\ 2Pendidikan Teknologi Kejuruan, Pasca Sarjana, Universitas Negeri Surabaya, Indonesia \\ *e-mail: bagus.dwicahyono@untirta.ac.id ${ }^{1}$ karno42@gmail.com ${ }^{2}$
}

\begin{abstract}
Abstrak
Permasalahan sampah merupakan permasalahan klasikyang masih sering terjadi, terutama di kota besar. Permasalahan dalam pengelolaan sampah di Desa Madyopuro, Malang cukup berat dimana dikarenakan minimnya ruang lapang yang dapat digunakan sebagai tepat pebuangan sapah dan kurangnya kesadaran masyarakat. Masyarakat masih ada yang membuang sampah sembarangan dan membakar sampah. Tujuan dari kegiatan pengabdian ini adalah memberikan gagasan pemberdayaan masyarakat dengan alternatif solusi berupa edukasi pengelolaan sampah rumah tangga. Metode yang digunakan yaitu penyuluhan kepada masyarakat dan penyebaran poster. Penyuluhan mengenai edukasi pengelolaan sampah menggunakan metode SOS (sort out, saved) dengan prinsip $5 R$ (reduce, reuse, recycle, replace dan replant) dan memahami peran bank sampah. Pada kegiatan pengabdian ini peneliti bekerja sama dengan SMKN 06 Malang sebagai tempat penyuluhan bank sampah. Hasil pengabdian kepada masyarakat yaitu meningkatkan motivasi warga desa dan merubah pola pikir mereka mengenai kesadaran lebih peduli terhadap lingkungan dan diharapkan untuk segera membuat kesepakatan dengan perangkat desa untuk membentuk bank sampah guna meminimalisir adanya timbulan sampah.
\end{abstract}

Kata kunci: Bank Sampah, Pengelolaan Sampah, Strategi

\begin{abstract}
The waste problem is a classic problem that still often occurs, especially in big cities. Problems in waste management in Madyopuro Village, Malang are quite severe due to the lack of field space that can be used for proper waste disposal and the lack of public awareness. There are still people who throw garbage carelessly and burn garbage. The purpose of this service activity is to provide ideas for community empowerment with alternative solutions in the form of education on household waste management. The method used is outreach to the community and poster distribution. Counseling on waste management education using the SOS (sort out, saved) method with the $5 R$ principle (reduce, reuse, recycle, replace and replant) and understand the role of the waste bank. In this service activity, the researchers collaborated with SMKN 06 Malang as a waste bank counseling site. The results of community service are increasing the motivation of villagers and changing their mindset about being more aware of caring for the environment and it is expected to immediately make an agreement with village officials to form a waste bank to minimize waste generation.
\end{abstract}

Keywords: Strategy, Waste Bank, Waste Management

\section{PENDAHULUAN}

Permasalahan sampah adalah permasalahan yang sering terjadi, terutama di kota besar. Masalah tersebut berupa lahan yang kurang dan kurangnya kesadaran diri masyarakat terhadap sampah yang dihasilkan. Di desa Madyopuro Malang permasalahan sampah merupakan permasalahan yang sangat pelik. Karena lahan kosong yang sangat sempit, sehingga banyak warga masyarakat desa Madyopuro yang kesusahan dalam menemukan tempat pembuangan sampah akhir. Hal ini menyebabkan banyak warga yang akhirnya membuang sampahnya sembarangan. Sampah yang menumpuk tersebut selain menjadi sumber bau tak sedap dan penyakit, timbunan sampah tersebut dapat menyebabkan banjir pada musim hujan.

Sampah adalah limbah yang bersifat padat terdiri dari zat organik dan zat anorganik yang dianggap tidak berguna dan harus dikelola agar tidak membahayakan lingkungan dan melindungi investasi pembangunan. Sampah adalah bahan sisa baik bahan-bahan yang tidak 
berguna lagi (barang bekas) maupun barang yang sudah tidak diambil bagian utamanya lagi. Dari segi lingkungan, sampah adalah bahan buangan yang tidak berguna dan banyak menimbulkan masalah pencemaran dan gangguan pada kelestarian lingkungan (Hikmah, 1999). ampah dipengaruhi oleh aktifitas manusia dan konsumsinya. Setiap aktifitas manusia menghasilkan sampah. Volume sampah berbanding lurus dengan tingkat konsumsi terhadap suatu barang yang gunakan setiap harinya. Demikian juga dengan jenis sampah sangat tergantung dari jenis material yang kita konsumsi (Mukono, 2006).

Manusia menghasilkan sampah dalam jumlah yang tidak sedikit pada setiap hari. Sampah dapat berasal dari berbagai kegiatan masyarakat seperti pertanian, pasar, rumah tangga, hiburan dan industri. Sampah yang dihasilkan dari kegiatan rumah tangga disebut sebagai sampah domestik (Sudiran, 2005). Jumlah pendudukan dan laju pertumbuhan penduduk perkotaan cenderung meningkat, hal tersebut menyebabkan sistem infrastruktur yang ada menjadi tidak memadai dan menyebabkan pemerintah harus bekerja keras dalam menangani permasalahan sampah (Riyanto, 2008).

Para ahli kesehatan masyarakat Amerika membuat batasan, sampah (waste) adalah sesuatu yang tidak digunakan, tidak dipakai, tidak disenangi, atau sesuatu yang dibuang, yang berasal dari kegiatan manusia, dan tidak terjadi dengan sendirinya.Dari batasan ini jelas bahwa sampah adalah hasil kegiatan manusia yang dibuang karena sudah tidak berguna.Dengan demikian sampah mengandung prinsip sebagai berikut: (1) Adanya sesuatu benda atau bahan padat; (2) Adanya hubungan langsung/tidak langsung dengan kegiatan manusia; daan (3) Benda atau bahan tersebut tidak dipakai lagi. (Notoatmojo, 2003)

Menurut Daniel (2009) pembagian sampah dibagi menjadi tiga jenis yaitu sampah organik, sampah anorganik, dan sampah bahan berbahaya dan beracun (B3) . Sampah organik adalah bahan yang dapat terurai melalui proses alamiah/biologis. Sampah jenis ini biasa disebut dengan sampah basah seperti sisa makanan, daun, dan lain-lain. Sampah anorganik merupakan sampah yang sulit terurai dengan proses biologis dalam waktu jangka panjang. Sampah ini disebut sampah kering seperti plastik, styrofoam, kaleng. Dan sampah B3 merupakan limbah yang berasal dari bahan-bahan berbahaya dan juga beracun seperti limbah pabrik tekstil, limbah rumah sakit, dan lain lain.

Masalah sampah akan selalu ada jika masyarakat masih memiliki sikap kurang kesadaran mengenai hal tersebut. Peran aktif masyarakat sangat dibutuhkan untuk mensukseskan pengelolaan sampah, terutama dalam mengurangi jumlah sampah, memilah jenis sampah serta mendaur ulang sampah. Keterlibatan masyarakat dalam proses pengelolaan sampah yaitu, mengupayakan agar sampah dikelola, dipilah dan diproses, dapat diawali dari lingkungan rumah tangga. Pengelolaan sampah akan mengurangi jumlah timbunan sampah yang harus dikumpulkan dan diangkut ke Tempat Pembuangan Sampah Sementara (Suwerda, 2012).

Adanya manajemen pengelolaan sampah yang baik sangat diperlukan dalam mengelola dan menjaga lingkungan untuk tetap bersih dan asri. Berdasarkan Undang-Undang Nomor 18 Tahun 2008 Tentang Pengelolaan Sampah disebutkan bahwa peran masyarakat turut berpatisipasi dalam pengelolaan sampah rumah tangga, dalam hal pengurangan (meliputi kegiatan pembatasan, penggunaan kembali, dan pendauran ulang) dan penanganan sampah (meliputi pemilahan, pengumpulan, pengangkutan, pengolahan, dan pemrosesan akhir).

Prinsip-prinsip yang dapat diterapkan dalam penanganan sampah misalnya dengan menerapkan prinsip 3-R, 4-R atau 5-R. Penanganan sampah 3-R adalah konsep penanganan sampah dengan cara Reduce (mengurangi), Reuse (menggunakan kembali), Recycle (mendaur ulang sampah), sedangkan 4-R ditambah Replace (mengganti) mulai dari sumbernya. Prinsip 5-R selain 4 prinsip tersebut di atas ditambah lagi dengan Replant (menanam kembali). Penanganan sampah 4-R sangat penting untuk dilaksanakan dalam rangka pengelolaan sampah padat perkotaan yang efisien dan efektif, sehingga diharapkan dapat mengurangi biaya pengelolaan sampah.

Bank sampah menjadi salah satu alternatif dalam strategi pengelolaan sampah (Asteria, 2016). Sampah selain menjadi permasalahan sendiri pada dampak lingkungan, juga menambah anggaran biaya dalam APBD Pemerintah. Bank sampah merupakan salah satu program yang dapat mengubah pola pandangan masyarakat terhadap pengelolaan sampah (Sekarningrum, 
2017). Pengelolaan Bank Sampah merupakan momentum awal membina kesadaran kolektif masyarakat untuk memulai memilah, mendaur-ulang, dan memanfaatkan sampah karena sampah mempunyai nilai jual yang cukup baik, sehingga pengelolaan sampah yang berwawasan lingkungan menjadi budaya baik di lingkungan masyarakat. Pengelolaan Bank Sampah menjadi salah satu solusi pengelolaan yang tepat untuk mewujudkan kemandirian dalam menegakkan budaya membuang sampah pada tempatnya.

Tujuan kegiatan pengabdian kepada masyarakat ini yaitu untuk mengetahui cara pengelolaan sampah hasil rumah tangga dan memberikan edukasi berupa solusi dalam pengelolaan sampah hasil rumah tangga di Desa Madyopuro melalui penyuluhan bank sampah. Sehingga melalui alternatif solusi yaitu memberikan penyuluhan terhadap pentingnya pengelolaan sampah rumah melalui bank sampah dapat membantu mengatasi permasalahan sampah rumah tangga di Desa Madyopuro. Dengan demikian melalui hasil laporan ini, diharapkan peneliti dapat memberikan gagasan/ide sebagai alternatif strategi bagi warga desa dalam pentingnya pengelolaan sampah rumah tangga berbasis pemberdayaan masyarakat melalui Bank Sampah di Madyopuro Malang.

\section{METODE}

Kegiatan dilaksanakan di SMKN 6 Malang pada tanggal 23 Novemmber 2019. Partisipan yang hadir merupakan perwakilan guru dan siswa SMKN 6 Malang serta perwakilan warga Desa Madyopuro Malang. Metode yang diterapkan dalam kegiatan pengabdian masyarakat ini adalah dengan menggunakan metode ceramah dan sosialisasi. Metode ceramah dilakukan dengan cara menjelaskan pada warga mengenai manajemen bank sampah sebagai bentuk sosialisasi program berkelanjutan. Kegiatan dalam pelaksanaan pengabdian kepada masyarakat di Desa Madyopuro Malang ini dimulai dari identifikasi masalah, penyuluhan, dan penyebaran poster. Kegiatan penyuluhan mengenai edukasi pengelolaan sampah menggunakan metode SOS (sort out, saved) dengan prinsip $5 \mathrm{R}$ (reduce, reuse, recycle, replace, dan replant) dan peranan bank sampah dalam desa.

Kegiatan ini diikuti oleh Kegiatan penyuluhan mengenai pengelolaan sampah ini dilakukan pada hari Sabtu, 23 November 2019 pada pukul 08.00 WIB yang diikuti oleh 100 peserta yang terdiri dari guru dan siswa SMKN 06 Malang dan masyarakat sekitar. Pada awal penyuluhan, narasumber menyampaikan materi tentang klasifikasi sampah, perencanaan dan pendirian bank sampah, serta manajemen bank sampah. Adapun sub pembahasan terdiri dari: jenis-jenis sampah organik dan anorganik, konsep bank sampah, peran serta masyarakat dalam pendirian bank sampah, jabatan dan divisi yang diperlukan dalam pelaksanaan bank sampah, kolaborasi peran antara masyarakat dan pemerintah daerah. Selain metode ceramah, dilaksanakan pula metode diskusi. Hal ini untuk mencari solusi atas permasalahan nyata yang ada di lapangan terkait dengan sampah dan lingkungan Kemudian dilanjutkan dengan kegiatan penyebaran poster pengelolaan sampah dengan konsep 5R. Kegiatan ini dilakukan pada hari Kamis, 28 November 2019 pada pukul 10.00 WIB. Penyebaran poster dilakukan di sepuluh tempat publik seperti di depan warung-warung yang biasa dikunjungi oleh warga Desa Madyopuro.

\section{HASIL DAN PEMBAHASAN}

Berdasarkan identifikasi permasalahan maka dirumuskan beberapa program kegiatan yaitu pelaksanaan penyuluhan bagi sekelompok guru dan siswa SMKN 06 Malang dan beberapa anggota karang taruna dan organisasi PKK di Desa Madyopuro guna meningkatkan pemahaman dan pengetahuan masyarakat dalam pengelolaan sampah menjadi nilai ekonomis melalui pembentukan bank sampah di Desa Madyopuro. Hasil dari kegiatan penyuluhan mengenai pengelolaan sampah 5R melalui bank sampah ini sangat diterima dengan antusias.

Melalui penyuluhan mengenai bank sampah akan berdampak positif baik secara ekonomi, sosial, maupun lingkungan bagi warga Desa Mayopuro dan SMKN 06 Malang. 
Penyuluhan gagasan mengenai bank sampah ini, yaitu memberikan informasi dan pemahaman bagi warga desa dan sekolah mengenai sistem kerja bank sampah melalui proses pengumpulan, pemilahan sampah anorganik yang disesuaikan dengan jenis dan kategori yang kemudian ditimbang dan ditabung di bank sampah, lalu untuk sampah organik yang dapat diolah menjadi pupuk kompos yang bisa diperjual belikan. Manfaat yang akan diperoleh oleh warga masyarakat dengan adanya bank sampah adalah masyarakat akan mendapat profit dengan mengumpulkan sampah sesuai dengan jenis dan jumlah yang ditentukan per-kg nya. Sementara bagi warga sekolah selain dapat memberikan pemasukan bagi warga sekolah juga dapat melatih siswa tentang pembelajaran non akademik seperti kewirausahaan.

Jika bank sampah ini dibentuk, anggota ataupun nasabah akan menyetorkan sampah anorganik yang akan dilakukan pencatatan kemudian ditimbang dan akhirnya memiliki harga sesuai dengan akumulasi jumlah sampah yang dikumpulkan oleh nasabah, dikalikan dengan daftar harga yang telah ditentukan oleh pengurus bank sampah dengan memperhitungkan biaya penyusutan kelengkapan bank sampah dan keuntungan bagi para nasabah. Lalu Bank sampah sudah bekerja sama dengan dinas terkait yang sudah ditunjuk dan disepakati, sehingga sampah yang sudah terkumpul langsung di angkat ke tempat pengolahan sampah berikutnya.

Melalui penyuluhan tersebut juga diinformasikan mengenai teknis kepengurusan bank sampah. Dimulai dengan kegiatan pemberdayaan masyarakat lokal melalui: (1) kelompok karang taruna; (2) organisasi PKK setempat; dan (3) Organisasi siswa intra sekolah (OSIS). Dalam kegiatan pemberdayaan tersebut dijelaskan mengenai urutan kegiatan manajemen bank sampah. Kegiatan penabungan sampah dilakukan setiap 2 minggu sekali yang mana penimbangan sampah dilakukan pada hari minggu. Teknis penimbangan sampah akan dilakukan oleh anggota ataupun nasabah bank sampah dilakukan di bank sampah yang telah disepakati secara bersama, dimana bagi masyarakat bisa karang taruna dan di sekolah adalah osis sebagai pengelola bank sampah. Bagi masyarakat dan siswa yang sebagai nasabah, mereka memperoleh prasarana berupa buku tabungan Sampah sebagai alat pencatatan hasil penimbangan sampah. Hasil timbangan tersebut kemudian di konversi ke dalam nilai rupiah yang kemudian ditulis di buku tabungan. Bank sampah sudah bekerja sama dengan dinas terkait yang sudah ditunjuk dan disepakati, sehingga sampah yang sudah terkumpul langsung di angkat ke tempat pengolahan sampah berikutnya.

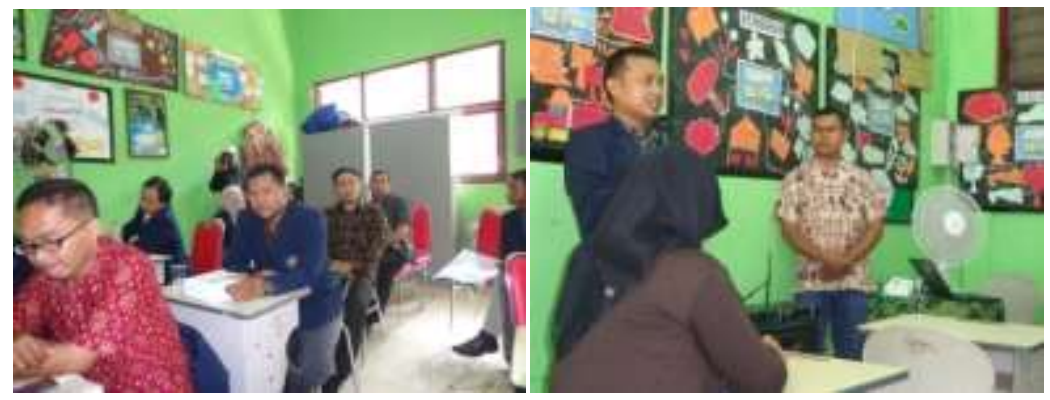

Gambar 1. Penyuluhan pengelolaan sampah

Setelah dilaksanakan kegiatan penyuluhan, selanjutnya dilaksanakan kegiatan penyebaran poster mengenai pengelolaan sampah dengan konsep $5 \mathrm{R}$ (reduce, reuse, recycle, replace, dan replant). Penyebaran poster dilakukan di sepuluh tempat publik seperti di depan warung-warung yang biasa dikunjungi oleh warga Desa Madyopuro Malang.

Pada kegiatan pengbdian ini yang menjadi indikator keberhasilan kegiatan yaitu nilai sosial, nilai ekonomi, dan lingkungan. Dalam indikator nilai sosial, sebelum adanya pengabdian yaitu kurangnya rasa kepedulian masyarakat terhadap penanganan sampah dilingkungan sekitar. Kemudian setelah dilakukan penyuluhan terlihat warga mulai memiiliki kesadara terhadap pengolahan sampah. Dimana pada saat pemasanagan poster terlhat timbunan sampah mulai berkurang. Selain itu dengan solusi yang ditawarkan dengan manajemen bank sampah dapat menciptakan budaya sehat dan bersih. Sementara dari indikator nilai ekonomi, sebelum adanya pengabdian masyarakat hanya mengetahui pengolahan sapah hanya dengan dibakar 
atau dengan membayar petugas kebersihan. Dengan adanya solusi yang ditawarkan berupa bank sampah dapat membantu masyarakat dala memberikan edukasi pengolahan sapah yang lebih bernilai ekonomis. Hasil pengabdian yang terjadi adalah masyarakat akan mendapatkan penghasilan seara mandiri melalui kegiatan tabungan bank sampah. Dan dalam indikator lingkungan, sebelum adanya pengabdian pada lingkugan desa karena kurangnya penanganan sampah oleh warga setempat berdampak pada adanya permasalahan di lingkungan sekitar berupa lingkungan yang kotor dan kumuh. Kemudian solusi atas permasalahan tersebut yaitu memberikan pemahaman mengenai pemilahan dan pengelolaan sampah. Hasil setelah pengabdian yaitu lingkungan akan menjadi bersih dan sehat.

\section{KESIMPULAN}

Hasil pelaksanaan kegiatan pengabdian dapat disimpulkan sebagai berikut: 1) Pelatihan Pengelolaam Bank Sampah bagi Masyarakat di Desa Madyopuro Malang bertujuan untuk mengedukasi dan memotivasi masyarakat tentang pentingnya pengelolaan sampah dengan baik. 2) Masyarakat telah mengetahui konsep pengelolaan sampah melalui $5 \mathrm{R}$ dan pemberdayaan bank sampah dan manfaat pengelolaan sampah melalui bank sampah setelah mengikuti kegiatan ini. 3) Masyarakat merasa termotivasi untuk selalu menjaga kebersihan lingkungan dan berperan dalam pengelolaan sampah melalui bank sampah.

\section{DAFTAR PUSTAKA}

Asteria, Donna \& Heru. (2016). Bank Sampah Sebagai Alternatif Strategi Pengelolaan Sampah Berbasis Masyarakat Di Tasikmalaya. Jurnal Manusia Dan Lingkungan, 23 (1): 136-141.

Daniel, V. (2009). Easy Green Living. Bandung: Hikmah

Hikmah, N. (1999). Tentang Studi Potensi Daur Ulang Sampah di TPA Tamanggapa Kota Makasar. Makasar : Politeknik Negeri Ujung Pandang

Mukono, H. (2006). Prinsip Dasar Kesehatan Lingkungan. Airlangga University Press (2), 157158)

Nasirudin, \& Triastianti, R. (2018). Potensi Reduce, Reuse, Recycle (3r) Sampah Domestik Pada Bank Sampah Di Kecamatan Umbulharjo Dan Kecamatan Pakualaman Kota Yogyakarta. Seminar Nasional \& Call For Paper, 114-115

Notoatmodjo, S. (2003). Pendidikan dan Perilaku Kesehatan. Jakarta: Rineka cipta

Republik Indonesia. (2008). Undang-Undang (UU) No. 18 Tahun 2008 Tentang Pengelolaan Sampah. Jakarta

Riyanto, B. (2008). Prospek Pengelolaan Sampah Nonkonvensional Di Kota Kecil (Studi Kasus: Kabupaten Gunungkidul). Tesis. Pascasarjana: Universitas Diponegoro. Semarang

Sekarningrum, Bintarsih, et all. (2017). Pengembangan Bank Sampah Pada Masyarakat Di Bantaran Sungai Cikapundung. Jurnal Pengabdian Kepada Masyarakat, 1(5):292-298

Sudiran.(2005). "Instrumen Sosial Masyarakat Karangmumus Kota Samarinda Dalam Penanganan Sampah Domestik". Journal Makara Sosial Humaniora (9), 16-17 


\section{Halaman Ini Dikosongkan}

